\title{
Maternal undernutrition during mid-pregnancy in sheep. Placental size and its relationship to calcium transfer during late pregnancy
}

\author{
BY G. J. MCCRABB*, A. R. EGAN AND B. J. HOSKING \\ School of Agriculture and Forestry, The University of Melbourne, \\ Parkville, Victoria 3052, Australia
}

(Received 15 December 1989 - Accepted 23 August 1990)

\begin{abstract}
The aim of the present experiment was to determine the relationship between placental and fetal weight after placental growth had been retarded by maternal undernutrition. Placental weight and fetal weight were measured in single-lamb-bearing ewes which were well-fed throughout pregnancy, or severely undernourished between the 30th and 96th day of pregnancy. Placental transfer of calcium and wholebody metabolism of both glucose and Ca were measured during late pregnancy. The change in fleeceadjusted live weight between the 30th and 96th day of pregnancy was 99 (SE 9.8) and - 146 (SE 9.6) g/d for the well-fed and undernourished ewes respectively. The condition score of well-fed ewes did not significantly change between the 96th (2.9 (SE 0.08)) and 140th (3.0 (SE 0.13)) day of pregnancy, while it increased from 1.6 (SE 0.15) to 2.3 (SE 0.11 ) for the previously undernourished group. Undernutrition caused an increase $(P<0.01)$ in placental weight measured on the 96th $(21 \%)$ and 140 th $(30 \%)$ day of pregnancy. In contrast fetal growth was not significantly affected by maternal undernutrition. While the voluntary dry matter intakes (g/d) of previously undernourished ewes after the 97th day of pregnancy were higher than for their well-fed counterparts, there was no significant difference between whole-body glucose or $\mathrm{Ca}$ metabolism, or the placental transfer of $\mathrm{Ca}$ measured during late pregnancy. This experiment confirms earlier reports of an increase in placental weight as a result of maternal undernutrition during mid-pregnancy; but the factors causing and the functional significance of this response have not been identified. Contrary to earlier proposals, placental weight per se did not limit fetal growth during late pregnancy. It is hypothesized that a combination of factors originating from maternal, placental and fetal sources act together to regulate growth of the fetus.
\end{abstract}

Undernutrition: Placenta: Calcium: Pregnancy: Sheep

When pregnant ewes have been subjected to a period of undernutrition before the 100th day of pregnancy, growth of the placenta has been reported to be retarded (Everitt, 1964; Morris, 1973; Mellor, 1983) or stimulated (Faichney, 1981; Owens et al. 1986 b). The level of body reserves in the ewe, as well as the timing and severity of the period of undernutrition, may explain some differences in the response of the placenta. However, the significance of placental weight arises from possible effects on the rate of fetal growth and, therefore, the birth weight attained. Mellor $(1983,1987)$ proposed that, in the well-fed ewe placental weight is the major determinant of growth rate of the fetus. This can only be true first, if placental weight is an appropriate index of the maximum functional ability of the placenta (i.e. its functional element), and second if the placenta is functioning at its maximum capacity as parturition approaches. In contrast to this hypothesis a preliminary experiment reported by Everitt (1965) demonstrated that a smaller placenta retarded by maternal undernutrition was not consistently associated with lower fetal weight at birth. Therefore, a clear relationship between placental weight and fetal growth has not yet been

* Present address: Toorak Research Station, Julia Creek, Queensland 4823, Australia. 
established. Attempts to clarify this relationship have been made by manipulation of placental weight using heat-stress (Bell et al. 1987 b) or a premating carunculectomy operation (Robinson et al. 1979; Owens et al. 1986a).

The objective of the experiment was to evaluate the consequence of different placental weight, resulting from maternal undernutrition before the 97th day of gestation, on birth weight of the lamb and on the transport of calcium across the placenta during late pregnancy. Ca was chosen as an index of placental transport because it is a nutrient essential for fetal growth and required at maximum levels during late pregnancy (Grace $e t$ al. 1986). It is transported across the placenta by means of a membrane-bound carrier mechanism (Comar, 1956; Braithwaite et al. 1972) as are other metabolically important substrates such as glucose (Widdas, 1952; Stacy et al. 1978) and some amino acids (Lemons et al. 1976). Ca transport across the placenta is readily determined because it is transferred across the placenta by a one-way process and deposited in the fetal body (Symonds et al. 1966; Braithwaite et al. 1972) without being mobilized or retained by the placenta. The transfer of Ca across the ovine placenta has been reviewed recently (Lester, 1986). If fetal growth is determined by placental weight then a change in placental weight will be associated with a proportional change in the net movement of nutrients across the placenta.

The present experiment confirmed earlier reports (e.g. Faichney \& White, 1987) that placental weight can be increased by maternal undernutrition during mid-pregnancy. However the larger placenta did not confer higher rates of fetal growth during late pregnancy. The birth weight of the lamb and the transport of $\mathrm{Ca}$ were not improved. Some of these results have been reported in a preliminary communication (McCrabb et al. 1987).

\section{MATERIALS AND METHODS}

Animals and management

Two groups of twelve 5-year-old Corriedale/Comeback ewes with oestrous cycles synchronized with medroxyprogesterone acetate (Repromap; Upjohn, Rydalmere, N.S.W. 2116) were treated 3 weeks apart, to permit sequential handling for experimental measurements. Two harnessed Merino rams, both weighing $74.8 \mathrm{~kg}$, were introduced to the flock and the days of mating were recorded. All ewes were run as one flock until the 30 th day of pregnancy when the nutritional treatments began.

Ewes in each mating group were allocated to one of two treatment groups. The well-fed (control, C) group was fed as one flock in the field with lucerne (Medicago sativa) hay (11.0 MJ metabolizable energy (ME) $/ \mathrm{kg}$ dry matter (DM) and $13.8 \mathrm{~g}$ nitrogen $/ \mathrm{kg} \mathrm{DM}$ ) ad lib. plus lupin (Lupinus angustifolius) grain (13.6 MJ ME/kg DM and $44.6 \mathrm{~g} \mathrm{~N} / \mathrm{kg} \mathrm{DM}$ ), during the period between the 30th and 96th day of pregnancy. The level of feed was calculated (Ministry of Agriculture, Fisheries and Food, 1984) to support a gain of approximately $100 \mathrm{~g} / \mathrm{d}$ in live weight between the 30th and 96th day of pregnancy. The under-fed (restricted, R) group was fed to produce a loss of $8 \mathrm{~kg}$ live weight between the 30 th and 96 th day of pregnancy. Group $\mathrm{R}$ ewes were housed in individual pens from the 30 th day of pregnancy, while group $C$ ewes remained in the field until the 65 th day of pregnancy and then housed until the time of slaughter.

At the 96th day of pregnancy, six ewes were selected for slaughter from each treatment group, according to live weight and condition score. At the time of slaughter one of the six group $\mathrm{R}$ ewes was found to be non-pregnant, and was excluded from the experiment. The remaining ewes in each group were given the same lucerne hay ad lib. until the 140th day of pregnancy, when they were also slaughtered. $A d$ lib. feeding during the final $44 \mathrm{~d}$ of the experiment was achieved by supplying $20 \%$ more DM than the previous days' consumption. 
All animals were treated for internal parasites with levamisole hydrochloride (Nilverm LV; Coopers, North Ryde, NSW 2113) and for external parasites with cyhalothrin (Grenade; ICI Aust. Operations Pty Ltd, Melbourne, Victoria 3000), before both the time of joining and housing. Animals were fed daily at 09.00 hours and fresh water was available at all times. The animals were weighed before feeding and condition scored (Russel et al. 1969) at least once each week during the study.

\section{Ewe slaughter and uterine dissection}

Ewes slaughtered on the 96th day of pregnancy were fasted for $24 \mathrm{~h}$ before their slaughter. Ewes slaughtered on the 140th day of pregnancy were not fasted before slaughter, to avoid interference with the metabolism of the ewe during the study of Ca transfer.

At the time of slaughter, the ewes were stunned with a captive bolt pistol before exsanguination. The uterus was removed through a $120 \mathrm{~mm}$ mid-line incision and tied off as close as possible to the cervix with cotton thread. After weighing the gravid uterus an incision was made along the greater curvature of the pregnant horn and the fetus exposed. The umbilical cord was tied off with cotton thread and severed. The fetus was immediately removed and killed with a lethal dose of pentobarbitone (Euthatal ${ }^{\circledR 3}$ 350; May and Baker, West Footscray, Victoria 3012), dried with paper towelling and weighed. The curved crown-rump length and thoracic girth were measured in triplicate with a length of cotton thread. The fetal membranes were dissected from the cotyledons using curved scissors. All cotyledons, including the fetal cotyledon and maternal caruncle, were then dissected from the uterine wall, counted and the total weight recorded.

\section{Whole-body entry rate of glucose}

The entry rate of glucose was determined on the 126th day of pregnancy. A PVC catheter was implanted in the jugular vein of each ewe at least $48 \mathrm{~h}$ before the beginning of the study. PVC catheter tubing $(1.0 \mathrm{~mm}$ i.d., $1.5 \mathrm{~mm}$ o.d.; Dural Plastics and Engineering, Dural, NSW 2158) was implanted into the left jugular vein via a $50 \mathrm{~mm} \times 14$ gauge hypodermic needle (Portland Surgical Products, Portland, Victoria 3305) and fixed in place with surgical suture (size 1/2.0 metric). A three-way tap (TOP Surgical Manufacturing Co. Ltd, Tokyo, Japan) was attached to the catheter tubing and fixed to the wither of the ewe for ease of sampling. Patency of the catheter was maintained by flushing daily with $1 \mathrm{ml}$ sterile (autoclaved) saline ( $9 \mathrm{~g}$ sodium chloride/l) containing $33 \mathrm{IU}$ sodium heparin (Weddel Pharmaceuticals, Thornleigh, NSW 2120).

The feeding strategy adopted on the day of study of glucose entry involved feeding oneeighth of the total daily ration at two-hourly intervals beginning at 06.00 hours, and ending at 20.00 hours (see Steel \& Leng, 1968). At 09.00 hours $5 \mathrm{ml}$ sterile saline containing $50 \mu \mathrm{Ci}$ $(1.85 \mathrm{mBq})\left[6-{ }^{3} \mathrm{H}\right] \mathrm{glucose}$ (Amersham International Plc, Amersham, Bucks, UK) and glucose carrier $(1 \mathrm{~g}$ glucose $/ 1)$ was injected into the non-catheterized jugular vein. Twelve blood samples were taken at $20 \mathrm{~min}$ intervals for the first $4 \mathrm{~h}$, and an additional five blood samples at less frequent intervals until $24 \mathrm{~h}$ after injection of the dose. At each time of sampling $10 \mathrm{ml}$ whole blood was withdrawn, placed in a tube containing $125 \mathrm{IU}$ lithium heparin (Disposable Products Pty Ltd, Technology Park, South Australia 5098) and placed on ice. The blood was then centrifuged at $750 \mathrm{~g}$ for $20 \mathrm{~min}$ and the plasma stored at $-20^{\circ}$ for later analysis.

Plasma was deproteinized with barium hydroxide and zinc sulphate (Somogyi, 1945) and assayed for glucose (Marks, 1959). The activity of $\left[{ }^{3} \mathrm{H}\right]$ glucose was determined by liquid scintillation counting (LS 3801; Beckman Instruments Inc., Irvine, CA 92713, USA) using 
a freeze-dried sample of deproteinized solution (Brockman \& Halvorson, 1981) reconstituted with $1 \mathrm{ml}$ water. ACS II scintillant ( $7 \mathrm{ml}$; Amersham Corporation, Arlington Heights, IL 60005, USA) was added before counting.

\section{Placental transfer of $\mathrm{Ca}$}

The procedure of Durand et al. (1983) was used to measure the rate of transfer of Ca from the dam to the fetus. A PVC catheter was implanted into the jugular vein of each ewe on the 131st day of pregnancy, using the same procedure as for the determination of the entry rate of glucose. At the $133 \mathrm{rd}$ day of pregnancy $500 \mu \mathrm{Ci}(18.5 \mathrm{MBq}){ }^{45} \mathrm{Ca}$ as $\mathrm{CaCl}_{2}$ (Australian Atomic Energy Commission, Lucas Heights, NSW 2234) in $5 \mathrm{ml}$ sterile (autoclaved) saline containing a carrier $\left(100 \mu \mathrm{g} \mathrm{Ca}\right.$ as $\left.\mathrm{CaCl}_{2} / \mathrm{ml}\right)$ was injected into the jugular vein of the dam at 09.00 hours. Following the injection of the dose, samples of whole blood $(8 \mathrm{ml})$ were taken; nineteen during the first $24 \mathrm{~h}$ and a further thirteen during the following $6 \mathrm{~d}$ until slaughter. The blood was immediately placed on ice in tubes containing $125 \mathrm{IU}$ lithium heparin, centrifuged at $750 \mathrm{~g}$ for $20 \mathrm{~min}$ and the plasma stored at $-20^{\circ}$ for later analysis. Immediately following withdrawal of the final blood sample on the 140th day of pregnancy, each ewe was slaughtered as described previously. The fetus was frozen, and minced through a $3 \mathrm{~mm}$ sieve, allowing a representative sample to be taken for ashing. Fetal tissue was ashed at $600^{\circ}$ for $16 \mathrm{~h}$ in a muffle furnace. The concentration of $\mathrm{Ca}$ in both maternal plasma and fetal ash was determined by atomic absorption spectroscopy (Willis, 1960, 1961). Plasma samples were deproteinized with trichloroacetic acid $(200 \mathrm{~g} / 1)$, freeze-dried and reconstituted with $1 \mathrm{ml} 2 \mathrm{M}$-hydrochloric acid. To suppress any interference by protein or phosphorus during $\mathrm{Ca}$ determination, strontium $\left(\mathrm{SrCl}_{2} .6 \mathrm{H}_{2} \mathrm{O}\right)$ was added to plasma (Willis, 1960) and fetal ash (Willis, 1961). Fetal ash dissolved in $2 \mathrm{M}-\mathrm{HCl}$ (about $75 \mu \mathrm{l}$ ) was made up to a volume of $1 \mathrm{ml}$ with distilled water. The activity of ${ }^{45} \mathrm{Ca}$ in both plasma and fetal ash was determined by liquid scintillation counting (LS 5801; Beckman Instruments Inc., Irvine, CA 92713, USA), in $7 \mathrm{ml}$ of ACS II scintillant (Amersham Corporation, Arlington Heights, IL 60005, USA), against a set of quenched standards.

\section{Calculations}

The decay curve for the specific activity of both glucose and $\mathrm{Ca}$ was described by calculating the line of best fit in the form:

$$
\mathrm{SR}_{t}=\sum_{i=1}^{n} A_{i} \mathrm{e}^{-m_{i} t}
$$

where $\mathrm{SR}_{t}$ is the specific radioactivity of glucose (disintegrations/min (dpm) per $\mathrm{mg}$ glucose) or $\mathrm{Ca}(\mathrm{dpm} / \mu \mathrm{g} \mathrm{Ca})$ at time $t ; A$ is the zero time intercept of each exponential component $(\mathrm{dpm} / \mathrm{mg}$ glucose or $\mathrm{dpm} / \mu \mathrm{g} \mathrm{Ca}) ; m$ is the rate-constant of each component $(/ \mathrm{min}) ; n$ is the number of components; $i$ is the component identification and $t$ is the time (min). Parameters were fitted by the least-squares method using the SAAM/CONSAAM computer program (Berman \& Weiss, 1978). Pool size, total entry rate and irreversible loss of glucose were calculated as described by White et al. (1969). The rate of Ca deposition was calculated using the method of Twardock et al. (1973). The mean specific activity of plasma $\mathrm{Ca}$ during the study of $\mathrm{Ca}$ transfer was calculated by dividing the area under equation 1 by the time duration of the study, that is $(\mathrm{dpm} \times \mathrm{min}) / \mathrm{min}$.

Ca transfer from the dam to the fetus was calculated as follows:

$$
\frac{\text { percentage }{ }^{45} \mathrm{Ca} \text { dose in fetus at slaughter }}{\text { mean specific activity of }{ }^{45} \mathrm{Ca} \text { in maternal plasma }}
$$




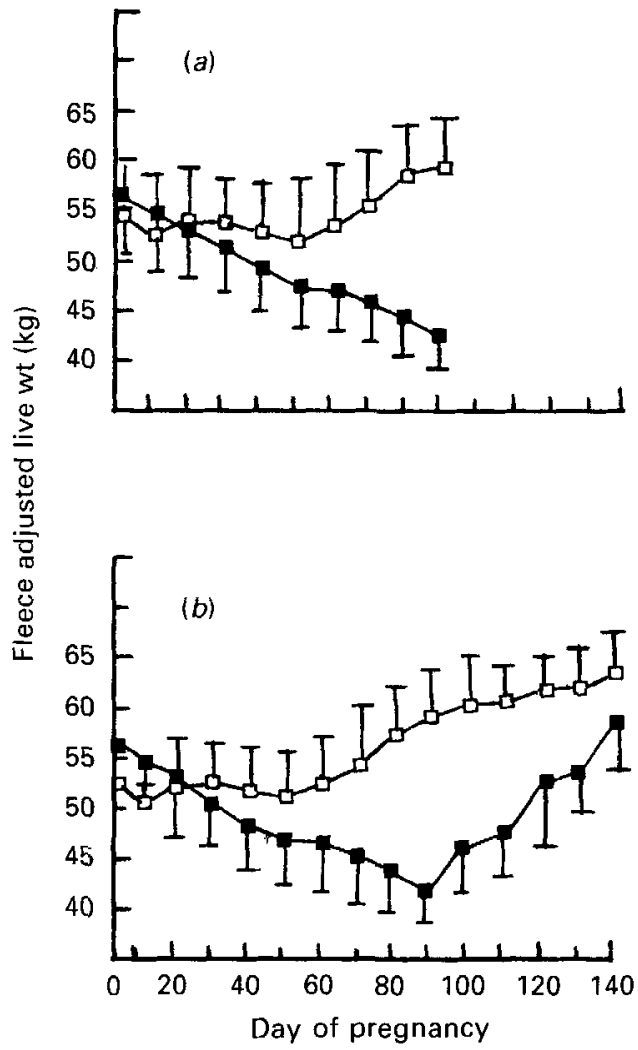

Fig. 1. Fleece-adjusted live weight of control $(\square)$ and restricted $(\square)$ ewes slaughtered at $(a) 96$ and $(b) 140 \mathrm{~d}$ of pregnancy. For details of dietary regimes and procedures, see pp. 158-159. Values are means with thejr standard errors represented by vertical bars.

\section{Statistical analysis}

Both $t$ test and two-way (treatment and day) analysis of variance (Nie, 1983) were used to test statistical differences between the treatment means. A least squares regression approach was incorporated into the analysis of variance to eliminate bias caused by unequal observations per cell (Nie, 1983).

\section{RESULTS}

\section{Live weight and condition score}

Fig. 1 shows the changes in fleece-adjusted live weight (FALW) of group $\mathrm{C}$ and $\mathrm{R}$ ewes slaughtered at the 96th and 140th day of pregnancy. The changes in FALW between the 30 th and 96th day of pregnancy for group C and R ewes were 99 (SE 9.8) and - 146 (SE 9.6) $\mathrm{g} / \mathrm{d}$ respectively. The FALW for group C ewes was greater $(P<0.01)$ at the 96 th day of pregnancy, but not significantly different at the 140th day of pregnancy. The increase in FALW between the 96th and 140th day of pregnancy was greater $(P<0.05)$ for group $\mathrm{R}$ than group $\mathrm{C}$. The condition scores of control and restricted ewes during the various stages of gestation are reported in Table 1 . 
Table 1. Condition score of control and restricted ewest during four stages of pregnancy (Mean values with their standard errors for no. of observations shown in parentheses)

\begin{tabular}{|c|c|c|c|c|c|c|}
\hline \multirow{2}{*}{$\begin{array}{l}\text { Day of } \\
\text { pregnancy }\end{array}$} & \multicolumn{3}{|c|}{ Control } & \multicolumn{3}{|c|}{ Restricted } \\
\hline & Mean & $\mathrm{SE}$ & $r$ & Mean & SE & $n$ \\
\hline Joining & $2 \cdot 3$ & 0.09 & $(12)$ & $2.5 \mathrm{NS}$ & 0.12 & (I1) \\
\hline 30 & 2.5 & $0 \cdot 16$ & (12) & $2 \cdot 4 \mathrm{NS}$ & $0 \cdot 10$ & (11) \\
\hline 96 & $2 \cdot 9$ & 0.08 & (12) & $1 \cdot 6^{* * *}$ & $0 \cdot 15$ & (11) \\
\hline 140 & 30 & 0.13 & (6) & $2 \cdot 3^{* * *}$ & 0.11 & (6) \\
\hline
\end{tabular}

NS, not significant.

Mean values were significantly different from control value ( $t$ test, pooled estimate of variance used): *** $P<$ $0 \cdot 001$.

$\dagger$ For details of dietary regimen and procedures, see pp. 158-159.

Table 2. Voluntary dry matter intake $(\mathrm{g} / \mathrm{d})$ of chaffed lucerne (Medicago sativa) hay by control and restricted ewes\$ during late pregnancy

(Mean values with their standard errors)

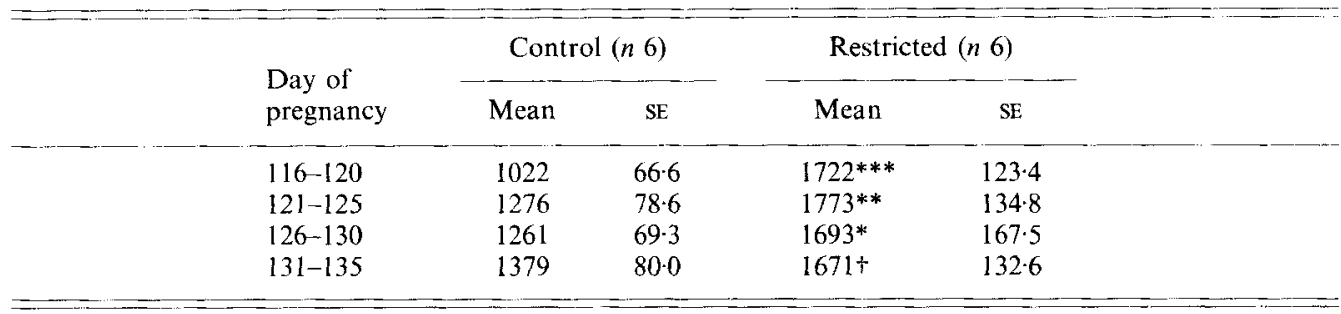

Mean values were significantly different from control values ( $t$ test, pooled estimate of variance used): ${ }^{*} P<0.05,{ }^{*} P<0.01, * * * P<0.001, \uparrow P<0 \cdot 10$.

$\$$ For details of dietary regimen and procedures, see pp. 158-159.

\section{DM intake}

The DM intake of group R ewes adjusted to provide the loss of weight described previously gradually declined from 800 to $210 \mathrm{~g}$ DM/ewe per $\mathrm{d}$ between the 30th and 96th day of pregnancy respectively. Voluntary DM intake during late pregnancy for group $\mathrm{C}$ was significantly lower than that for group $\mathrm{R}$ ewes (Table 2).

\section{Placental and fetal components}

There was no significant effect of undernutrition on fetal weight or dimensions when measured at either the 96th or 140th day of pregnancy (Table 3). No significant difference was observed at the 96 th day of pregnancy between the group $\mathrm{C}(n 6)$ and $\mathrm{R}(n 5)$ fetuses in the weight (g) of the brain (19 (SE 0.9), 19 (SE 0.8)), liver (41 (SE 3.8), 39 (SE 2.7)), heart (8 (SE 0.9), 7 (SE 0.9)), lung (33 (SE 1.6), 30 (SE 2.2)), right kidney (5 (SE 0.3), 5 (SE 0.4)) or left kidney $(5(\mathrm{SE} 0 \cdot 3), 5(\mathrm{SE} 0 \cdot 4))$ respectively, or when they were expressed as a proportion of fetal weight. The weight of the fetus, its crown-rump length and thoracic girth increased $(P<0.01)$ between the 96 th and 140 th day of pregnancy. The weight of the placenta of group $\mathrm{R}$ ewes was greater $(P<0.01)$ than for group $\mathrm{C}$ ewes at both the 96th and 140th day of pregnancy (Table 3 ). There was no significant difference in the number of cotyledons for groups $\mathrm{C}$ and $\mathrm{R}$ ewes at either stage of gestation. 
Table 3. Contents of the gravid uterus of control and restricted ewes* at the 96 th and 140 th day of pregnancy

(Mean values for no. of ewes in parentheses)

\begin{tabular}{|c|c|c|c|c|c|c|c|c|c|c|}
\hline \multirow[b]{2}{*}{ Day of pregnancy... } & \multicolumn{2}{|c|}{$\begin{array}{c}\text { Fetus }{ }^{\dagger} \\
(\mathrm{g})\end{array}$} & \multicolumn{2}{|c|}{$\begin{array}{l}\text { Crown-rump } \\
\text { length }(\mathrm{mm})\end{array}$} & \multicolumn{2}{|c|}{$\begin{array}{l}\text { Thoracic } \\
\text { girth (mm) }\end{array}$} & \multicolumn{2}{|c|}{$\begin{array}{l}\text { Placenta } \\
\text { (g) }\end{array}$} & \multicolumn{2}{|c|}{$\begin{array}{c}\text { Cotyledon } \\
\text { no. }\end{array}$} \\
\hline & 96 & 140 & 96 & 140 & 96 & 140 & 96 & 140 & 96 & 140 \\
\hline Control & $\begin{array}{l}644 \\
(6)\end{array}$ & $\begin{array}{c}4552 \\
(6)\end{array}$ & $\begin{array}{l}303 \\
(6)\end{array}$ & $\begin{array}{l}549 \\
(6)\end{array}$ & $\begin{array}{l}170 \\
(6)\end{array}$ & $\begin{array}{l}339 \\
(6)\end{array}$ & $\begin{array}{l}496 \\
(6)\end{array}$ & $\begin{array}{l}430 \\
(6)\end{array}$ & $\begin{array}{l}83 \\
(6)\end{array}$ & $\begin{array}{r}87 \\
(6)\end{array}$ \\
\hline Restricted & $\begin{array}{l}686 \\
(5)\end{array}$ & $\begin{array}{c}4561 \\
(6)\end{array}$ & $\begin{array}{l}296 \\
(5)\end{array}$ & $\begin{array}{l}554 \\
(6)\end{array}$ & $\begin{array}{l}170 \\
(5)\end{array}$ & $\begin{array}{l}339 \\
(6)\end{array}$ & $\begin{array}{l}600 \\
(5)\end{array}$ & $\begin{array}{l}560 \\
(6)\end{array}$ & $\begin{array}{l}88 \\
(5)\end{array}$ & $\begin{array}{l}82 \\
(6)\end{array}$ \\
\hline \multicolumn{11}{|l|}{ Statistical significance +} \\
\hline $\begin{array}{l}\text { Day of pregnancy } \\
\text { Control } v \text {. restricted } \\
\text { Interaction } \\
\mathrm{SE}\end{array}$ & & 30 & $\begin{array}{c}P< \\
1 \\
1 \\
1\end{array}$ & 01 & $P<$ & & $P$ & 01 & & \\
\hline
\end{tabular}

NS, not significant.

* For details of dietary regimen and procedures, see pp. 158-159.

$\uparrow$ Statistical analysis done on log transformed data, SE from log analysis.

$\ddagger$ Two-way (treatments and days) analysis of variance.

\section{Glucose metabolism}

There was no significant difference between group $\mathrm{C}(n 4)$ and $\mathrm{R}(n$ 5) ewes in the concentration of glucose in maternal plasma (mmol/1; 3.8 (SE 0.21), 3.4 (SE 0.07)), pool size (mmol; 42 (SE 3.8), 36 (SE 3.6)), entry rate (mmol/min; 0.72 (SE 0.059), 0.84 (SE 0.075)) or irreversible loss ( $\mathrm{mmol} / \mathrm{min} ; 0.63$ (SE 0.048), 0.72 (SE 0.078)) of glucose on the 126th day of pregnancy respectively. When both entry rate and irreversible loss of glucose were expressed as proportions of ewe live weight, they were lower $(P<0.05)$ for group $\mathrm{C}$ ( $\mathrm{mmol} / \mathrm{min}$ per $\mathrm{kg} ; 0.011$ (SE 0.0004), 0.010 (SE 0.0003)) than group $\mathrm{R}(\mathrm{mmol} / \mathrm{min}$ per $\mathrm{kg}$; 0.017 (SE 0.0014), 0.014 (SE 0.0015)) ewes respectively. There was no significant difference in pool size when expressed as a proportion of ewe live weight.

\section{Metabolism and transfer of $\mathrm{Ca}$ across the placenta}

There was no significant difference between group $\mathrm{C}(n 6)$ and $\mathrm{R}(n 6)$ ewes in the concentration of $\mathrm{Ca}$ in maternal plasma $(\mu \mathrm{mol} / \mathrm{ml} ; 2.6$ (SE 0.06), 2.5 (SE 0.08)), pool size (mmol; 47 (SE 1.7), 47 (SE 4.9)), entry rate ( $\mathrm{mmol} / \mathrm{h} ; 5.5(\mathrm{sE} \mathrm{0.30)}$, 5.5 (SE 0.52)) or irreversible loss (mmol/h; 3.6 (SE 0.24), 3.7 (SE 0.31)) of Ca measured during the period between the $133 \mathrm{rd}$ and 140th day of pregnancy respectively. There was no significant difference in the percentage of the ${ }^{45} \mathrm{Ca}$ dose deposited in the fetus, or the rate of deposition of total (stable) $\mathrm{Ca}$ in the fetus between the 133rd and 140th day of pregnancy in group $\mathrm{C}$ and group $\mathrm{R}$ ewes (Table 4). The percentge of the ${ }^{45} \mathrm{Ca}$ dose deposited $(P<0.05)$, and the rate of deposition of $\mathrm{Ca}(P<0.05)$ when expressed as a proportion of the weight of the placenta was higher for group $\mathrm{C}$ than group $\mathrm{R}$ ewes. The rate of deposition of $\mathrm{Ca}$ expressed as a proportion of the weight of the fetus was not significantly different between group $\mathrm{C}$ and $\mathrm{R}$ ewes.

\section{DISCUSSION \\ Fetal growth}

The period of severe maternal undernutrition between the 30th and 96th day of pregnancy did not affect growth of the fetus, measured in terms of either its body-weight or the size 
Table 4. Variables of placental transfer of calcium in control and restricted ewes* measured between the 133rd and 140th day of pregnancy

(Mean values with their standard errors)

\begin{tabular}{|c|c|c|c|c|c|}
\hline & \multicolumn{2}{|c|}{ Control $(n 6)$} & \multicolumn{2}{|c|}{ Restricted ( $n$ 6) } & \multirow{2}{*}{$\begin{array}{c}\text { Statistical } \\
\text { significance } \\
\text { of difference } \dagger\end{array}$} \\
\hline & Mean & $\mathrm{SE}$ & Mean & $\mathrm{SE}$ & \\
\hline $\begin{array}{l}\text { Percentage of dose } \\
\text { deposited in fetus: } \\
\% \\
\% / g \text { placenta } \times 100 \\
\% / g \text { fetus } \times 1000\end{array}$ & $\begin{array}{r}39 \cdot 4 \\
9 \cdot 3 \\
8 \cdot 8\end{array}$ & $\begin{array}{l}1 \cdot 34 \\
0 \cdot 68 \\
0 \cdot 52\end{array}$ & $\begin{array}{r}37 \cdot 5 \\
6 \cdot 9 \\
8 \cdot 4\end{array}$ & $\begin{array}{l}2 \cdot 49 \\
0.67 \\
0.69\end{array}$ & $\begin{array}{l}\text { NS } \\
P<0.05 \\
\quad \text { NS }\end{array}$ \\
\hline $\begin{array}{l}\text { Rate of } \mathrm{Ca} \text { deposition: } \\
\mathrm{mmol} / \mathrm{d} \\
\mathrm{mmol} / \mathrm{d} \text { per } \mathrm{kg} \text { placenta } \\
\mathrm{mmol} / \mathrm{d} \text { per } \mathrm{kg} \text { fetus }\end{array}$ & $\begin{array}{l}35 \cdot 0 \\
80 \\
7 \cdot 5\end{array}$ & $\begin{array}{l}2 \cdot 5 \\
5 \cdot 2 \\
0 \cdot 35\end{array}$ & $\begin{array}{l}35 \cdot 0 \\
62 \\
7 \cdot 5\end{array}$ & $\begin{array}{l}2 \cdot 5 \\
3 \cdot 0 \\
0 \cdot 30\end{array}$ & $\begin{array}{l}\text { NS } \\
P<0 \cdot 05 \\
\quad \text { NS }\end{array}$ \\
\hline $\begin{array}{l}\text { Total Ca in fetus: } \\
\text { mol } \\
\text { mol } / \mathrm{kg} \text { placenta } \\
\text { mol } / \mathrm{kg} \text { fetus }\end{array}$ & $\begin{array}{l}0.97 \\
2 \cdot 3 \\
0 \cdot 22\end{array}$ & $\begin{array}{l}0 \cdot 034 \\
0 \cdot 01 \\
0 \cdot 009\end{array}$ & $\begin{array}{l}0 \cdot 98 \\
1 \cdot 8 \\
0 \cdot 22\end{array}$ & $\begin{array}{l}0.063 \\
0 \cdot 01 \\
0 \cdot 007\end{array}$ & $\begin{array}{l}\text { NS } \\
P<0.05 \\
\quad \mathrm{NS}\end{array}$ \\
\hline
\end{tabular}

NS, not significant.

* For details of dietary regimen and procedures, see pp. 158 and 160 .

$\dagger t$ test, pooled estimate of variance used.

of the individual organ and tissue components. This is in contrast to a number of studies on the effect of maternal undernutrition which have reported either an increase (Everitt, 1965; Russel et al. 1981; Holst et al. 1986; Faichney \& White, 1987) or a decrease (Everitt, 1965; Morris, 1973; Curll et al. 1975; Rattray \& Trigg, 1979; Russel et al. 1981; Mellor, 1983; Nordby et al. 1986) in birth weight of the lamb. The reasons for these various responses have not been established, but it seems likely that in the present experiment, the mobilization of the maternal body tissue and a shift in the factors regulating the partition of nutrients by the dam, were able to buffer growth of the fetus from any effect of severe maternal feed restriction. It has previously been hypothesized that these different responses in fetal growth and birth weight of the lamb are directly related to placental weight (Davis et al. 1981; Mellor, 1983; Holst et al. 1986; Kelly, 1986; Faichney \& White, 1987), but a clear relationship has not been demonstrated. Both Davis et al. (1981), Kelly (1986) and Kelly \& Ralph (1988) have proposed that feeding the ewe in specific ways can alter placental weight and affect fetal growth. The relationship between placental weight and fetal weight at the 140th day of pregnancy in the present experiment was poor. Clearly variability in fetal weight was not determined by placental weight alone.

\section{Intake and metabolism}

Voluntary DM intakes during late pregnancy were higher for the previously under-fed (group R) ewes than for their well-fed (control) counterparts, and confirm similar observations made in mature wethers of the same genetic background (Djajanagara, 1986). During the periods between the 116th and 120th, and the 131st and 135th day of pregnancy the intake of group $\mathrm{R}$ ewes was $68 \%(P<0.001)$ and $21 \%$ (not significant) greater respectively than group $\mathrm{C}$ ewes. The calculated intakes of $\mathrm{ME}, \mathrm{N}$ and $\mathrm{Ca}$ of group $\mathrm{C}$ $(+17 \%,+19 \%,+300 \%)$ and group $\mathrm{R}(+25 \%,+44 \%,+600 \%)$ ewes were well above the currently recommended allowances (Agricultural Research Council, 1980), and indicate that intake was not limiting the supply of nutrients during late pregnancy. Despite the 
difference in intake, and the higher rate of gain in live weight and condition score of group $\mathrm{R}$ compared with group $\mathrm{C}$ ewes, the entry rates of both glucose and Ca by the dam during late pregnancy were similar between treatment groups. In addition the whole-body entry rate of glucose was higher $(20 \%)$ than in other reports (Leng, 1970). Therefore, the maternal pool of nutrients available for transfer to the fetus was assumed to be not limiting the supply of nutrients for fetal growth. The potential supply of glucose, which is one of the major metabolic substrates required by the fetus (Battaglia \& Meschia, 1981; Mellor, 1983), was similar for all ewes and was not affected by the level of feeding during early and mid-pregnancy. In addition, the concentration of glucose in maternal plasma, which is the driving force for glucose transport (Jodarski et al. 1985; Rankin et al. 1986), was similar for both groups of ewes. It is supposed that the rate at which glucose was partitioned to the fetus during late pregnancy was similar for both groups, as reflected in the fetuses of similar weight when measured at the 140th day of pregnancy.

\section{Placental growth}

Placental growth was more sensitive than fetal growth to maternal undernutrition during mid-pregnancy, and confirms the observations made in an earlier study (McCrabb et al. 1986). The nutritional restriction resulted in a 104 and $130 \mathrm{~g}$ larger $(P<0.01)$ placental weight in group $\mathrm{R}$ than group $\mathrm{C}$ when measured at the 96th and 140th day of pregnancy respectively. These differences are intermediate between $148 \mathrm{~g}$ (Faichney \& White, 1987) and $25 \mathrm{~g}$ (Owens et al. 1986 b), both measured at the 135th day of pregnancy. The decline in weight of the placenta during late pregnancy of control (well-fed) ewes followed the normal pattern of growth (Bell, 1984). In addition, the commonly observed non-significant decline in weight of the placenta during late pregnancy of group $\mathrm{R}$ ewes was lower than for group $\mathrm{C}$ ewes in both the present $(40 v .68 \mathrm{~g})$ and an earlier $(10 v .44 \mathrm{~g})$ experiment (McCrabb et al. 1986).

The observations of Faichney \& White (1987) demonstrate that ewes which had a larger placenta as a result of maternal feed restriction, also exhibited higher rates of fetal growth. In contrast, the present experiment has demonstrated that the smaller placenta of group C ewes has, at least, the same capacity as the larger placenta of group $\mathrm{R}$ ewes for the transport of nutrients for growth of the fetus.

\section{Placental transport}

The transport of $\mathrm{Ca}$ across the placenta was chosen as a suitable indicator of fetal growth because it is actively transported across the placental barrier as are other metabolically important substrates such as glucose and some amino acids (Lemons et al. 1976). Second, the major sink of $\mathrm{Ca}$ in the growing fetus is its skeleton. Since the size of the fetal skeleton is related to fetal weight (Gabbedy, 1974), the placental transfer of Ca should be an index of fetal growth. It is possible that the compartmental kinetics of ${ }^{45} \mathrm{Ca}$ irreversible loss in the pregnant ewe may provide a sufficiently sensitive estimate of fetal growth during late pregnancy to be used in future studies of fetal growth. Validation of this hypothesis is required to determine its potential uses.

The rate of $\mathrm{Ca}$ transfer observed in the present study $(7.5 \mathrm{mmol} / \mathrm{d}$ per $\mathrm{kg}$ fetus $)$ was similar to previous measurements made by Field \& Suttle (1967), 8.2 mmol/d per kg; Braithwaite et al. (1970), $9.0 \mathrm{mmol} / \mathrm{d}$ per $\mathrm{kg}$; and Twardock et al. (1973), $7.4 \mathrm{mmol} / \mathrm{d}$ per $\mathrm{kg}$. Placental weight per se was not an accurate indicator of the rate of transport of nutrients across the placenta during late pregnancy, as the rate of movement of Ca across the placenta was $35 \mathrm{mmol} / \mathrm{d}$ for both previously restricted (group R) and control (well-fed, group $\mathrm{C}$ ) ewes. Alternatively, when the rate of transfer of $\mathrm{Ca}$ was expressed relative to placental weight, it was higher for control $(80 \mathrm{mmol} / \mathrm{d}$ per $\mathrm{kg}$ placenta) than restricted (62 
$\mathrm{mmol} / \mathrm{d}$ per $\mathrm{kg}$ placenta) ewes. This is consistent with the proposal that the mechanisms involved in the transfer of $\mathrm{Ca}$ across the placenta are not limiting nutrient transfer during normal growth. The factors regulating the rate of growth of the fetus during late pregnancy appear to originate from sources other than the placenta alone. Ca may not have limited fetal growth, although its transport was probably controlled by fetal growth processes, in turn limited by another nutrient. This hypothesis is supported by recent evidence which has shown that a hormone (parathyroid hormone-related protein), produced in the parathyroid gland of the ovine fetus, is responsible for stimulating the transport of $\mathrm{Ca}$ across the placenta and thus maintaining fetal hypercalcaemia (Loveridge et al. 1988; Rodda et al. 1988). Since the rate of deposition of Ca across the placenta was the same for both control and previously restricted groups, it is proposed that the fetus itself may be regulating $\mathrm{Ca}$ transport.

It is, therefore, hypothesized that placental weight per se does not limit fetal growth but rather that a combination of maternal, fetal and placental factors all interact to regulate fetal growth. The similar rates of transfer of ${ }^{45} \mathrm{Ca}$ across placentas of different weights support this proposal. Twardock et al. (1973) demonstrated that the lower placental weight associated with twin fetuses was not associated with an alteration in the rate of transport of $\mathrm{Ca}$ across the placenta. Since placental weight associated with individual twin fetuses is smaller than their single-bearing counterparts (Stegeman, 1974), it can be inferred that the smaller placental weight for twin fetuses does not limit the transport of $\mathrm{Ca}$ across the placenta.

Clearly the physiological settings which were regulating the partition of nutrients were vastly different between the two treatment groups. During late pregnancy leaner ewes had less body reserves to mobilize, consumed a greater amount of feed and increased in live weight and condition score more than did the previously well-fed control ewes. Despite these differences, growth of the fetus remained unaffected, suggesting that either (1) the factors regulating growth of the fetus were independent of the physiological status of the ewe, or (2) that the control of the partition of nutrients in the ewe was altered, despite severe maternal undernutrition, to maintain similar rates of fetal growth (see Bauman \& Currie, 1980; Bell et al. 1987a). The main assumptions contained in the hypothesis proposed by Mellor (1983) are not supported by the present findings. It is concluded that placental weight per se does not limit fetal growth in ewes with adequate current nutrition during late pregnancy.

The authors are grateful to Mrs Janet Beard for her technical assistance in the operation of the atomic absorption spectrophotometer, to Professor N. M. Tulloh and Dr R. Sainz for their helpful comments on this manuscript, and for the various assistance given by $\mathrm{Mr}$ Daryl Whitfield, Mr Andre Thalen and Mr Roy Thomas. This research was supported by the Wool Research Trust Fund on the recommendation of the Australian Wool Corporation. One of us (G.J.M.) gratefully acknowledges receipt of an Australian Wool Corporation Postgraduate Scholarship.

\section{REFERENCES}

Agricultural Research Council (1980). Feeding Requirements of Ruminant Livestock. London: Commonwealth Agricultural Bureaux.

Battaglia, F. C. \& Meschia, G. (1981). Foetal and placental metabolisms: their interrelationship and impact on maternal metabolism. Proceedings of the Nutrition Society 40, 99-113.

Bauman, D. E. \& Currie, W. B. (1980). Partitioning of nutrients during pregnancy and lactation: a review of mechanisms involving homeostasis and homeorhesis. Journal of Dairy Science 63, 1514-1529.

Bell, A. W. (1984). Factors controlling placental and foetal growth and their effect on future production. In 
Reproduction in Sheep, pp. 144-152 [D. R. Lindsay and D. T. Pearce, editors]. Canberra: Australian Academy of Science and Australian Wool Corporation.

Bell, A. W., Bauman, D. E. \& Currie, W. B. (1987a). Regulation of nutrient partitioning and metabolism during pre- and post-natal growth. Journal of Animal Science 65 (Suppl. 2), 186-212.

Bell, A. W., Wilkening, R. B. \& Meschia, G. (1987 b). Some aspects of placental function in chronically heatstressed ewes. Journal of Developmental Physiology 9, 17-29.

Berman, M. \& Weiss, M. F. (1978). SAAM Manual (Simulation, Analysis and Modelling). Version 27, Dhew Publication no. (NIH) 78-180. Bethesda, Maryland: Laboratory of Theoretical Biology, National Cancer Institute, National Institute of Health.

Braithwaite, G. D., Glascock, R. F. \& Riazuddin, S. H. (1970). Calcium metabolism in pregnant sheep. British Journal of Nutrition 24, 661-670.

Braithwaite, G. D., Glascock, R. F. \& Riazuddin, S. H. (1972). Studies on the transfer of calcium across the ovine placenta and incorporation into the foetal skeleton. British Journal of Nutrition 27, 417-424.

Brockman, R. P. \& Halvorson, R. (1981). Effect of somatostatin and adrenergic blockade on glucagon, insulin and glucose in exercising sheep. Australian Journal of Biological Science 34, 551-560.

Comar, C. L. (1956). Radiocalcium studies in pregnancy. Annals of the New York Academy of Sciences 64, $281-297$.

Curll, M. L., Davidson, J. L. \& Freer, M. (1975). Efficiency of lamb production in relation to the weight of the ewe at mating and during pregnancy. Australian Journal of Agricultural Research 26, 553-565.

Davis, S. R., Rattray, P. V., Petch, M. E. \& Duganzich, D. M. (1981). Interrelationships of placental development with nutrition in pregnancy and lamb birth weight. Proceedings of the New Zealand Society of Animal Production 41, 218-223.

Djajanagara, A. (1986). Intake and digestion of cereal straws by sheep. PhD Thesis, University of Melbourne, Victoria, Australia.

Durand, D., Braithwaite, G. D. \& Barlet, J. P. (1983). The effect of 1 alpha-hydroxycholecalciferol on the placental transfer of calcium and phosphate in sheep. British Journal of Nutrition 49, 475-480.

Everitt, G. C. (1964). Maternal undernutrition and retarded foetal development in the merino sheep. Nature 201, 1341-1342.

Everitt, G. C. (1965). The effect of maternal nutrition on foetal growth. PhD Thesis, University of Adelaide, South Australia.

Faichney, G. J. (1981). Amino acid utilization by the foetal lamb. Proceedings of the Nutrition Society of Australia $6,48-53$.

Faichney, G. J. \& White, G. A. (1987). Effects of maternal nutritional status on fetal and placental growth and on fetal urea synthesis in sheep. Australian Journal of Biological Science 40, 365-377.

Field, A. C. \& Suttle, N. L. (1967). Retention of calcium, phosphorus, magnesium, sodium and potassium by the developing sheep foetuses. Journal of Agricultural Science, Cambridge 69, 417-423.

Gabbedy, B. J. (1974). A growth comparison of single and twin lambs during pre-natal and early post-natal life. MAgrSc Thesis, University of Melbourne, Parkville, Victoria, Australia.

Grace, N. D., Watkinson, J.H. \& Martinson, P. L. (1986). Accumulation of minerals by the foetus(es) and conceptus of single- and twin-bearing ewes. New Zealand Journal of Agricultural Research 29, $207-222$.

Holst, P. J., Killeen, I. D. \& Cullis, B. R. (1986). Nutrition of the pregnant ewe and its effect on gestation length, lamb birth weight and lamb survival. Australian Journal of Agricultural Research 37, 647-655.

Jodarski, G. D., Shanahan, M. F. \& Rankin, J. H. G. (1985). Fetal insulin and placental 3- $O$-methyl glucose clearance in near term sheep. Journal of Developmental Physiology 7, 321-332.

Kelly, R. W. (1986). Reproductive wastage in sheep. Journal of Agriculture (Western Australia) 22, 22-26.

Kelly, R. W. \& Ralph, I. G. (1988). Lamb and wool production from ewes fed differentially during pregnancy. Proceedings of the Australian Society of Animal Production 17, 218-225.

Lemons, J. A., Adcock, E. W., Jones, M. W., Naughton, M. A., Meschia, G. \& Battaglia, F. C. (1976). Umbilical uptake of amino acids in the unstressed fetal lamb. Journal of Clinical Investigation 58, 1428-1434.

Leng, R. A. (1970). Glucose synthesis in ruminants. Advances in Veterinary Science 14, 209-260.

Lester, G. E. (1986). Cholecalciferol and placental calcium transfer. Federation Proceedings 45, 2524-2527.

Loveridge, N., Caple, I. W., Rodda, C., Martin, T. J. \& Care, A. D. (1988). Further evidence for a parathyroid hormone-related protein in fetal parathyroid glands of sheep. Quarterly Journal of Experimental Physiology 73 , $781-784$

McCrabb, G. J., Hosking, B. J. \& Egan, A. R. (1986). Placental size and foetal growth in relation to maternal undernutrition during mid-pregnancy. Proceedings of the Nutrition Society of Australia 11, 147.

McCrabb, G. J., Hosking, B. J. \& Egan, A. R. (1987). Nutritional manipulation of placental size not the key to higher foetal growth. Proceedings of the Nutrition Sociefy of Australia 12, 87.

Marks, V. (1959). An improved glucose-oxidase method for determining blood, C.S.F. and urine glucose levels. Clinica Chimica Acta 4, 395-400.

Mellor, D. G. (1983). Nutritional and placental determinants of foetal growth rate in sheep and consequences for the newborn lamb. British Veterinary Journal 139, 307--324.

Mellor, D. G. (1987). Nutritional effects on the foetus and mammary gland during pregnancy. Proceedings of the Nutrition Society 46, 249-257. 
Ministry of Agriculture, Fisheries and Food (1984). Energy Allowances and Feeding Systems for Ruminants. Reference Book 433. London: H.M. Stationery Office.

Morris, G. A. M. (1973). The performance of the merino ewe and lamb as influenced by nutrition during pregnancy. MRurSc Thesis, University of New England, Armidale, NSW, Australia.

Nie, N. H. (1983). SPSSX User's Guide (A Complete Guide to SPSSX Language and Operations). New York: McGraw-Hill Book Company.

Nordby, D. J., Fiejd, R. A., Riley, M. L., Johnson, C. L. \& Kercher, C. J. (1986). Effects of maternal undernutrition during early pregnancy on postnatal growth in lambs. Proceedings (Western Section) American Society of Animal Science 37, 92-95.

Owens, J. A., Falconer, J. \& Robinson, J. S. (1986a). Effect of restriction of placental growth on umbilical and uterine blood flows. American Journal of Physiology 250, R427-R434.

Owens, J. L., Kyle, B. \& Fennessy, P. F. (1986 b). Observations on the effect of litter size, pregnancy nutrition and fat genotype on ewe and foetal parameters. Proceedings of the New Zealand Journal of Animal Production 46. $41-44$.

Rankin, J. H. G., Jodarski, G. \& Shanahan, M. R. (1986). Maternal insulin and placental 3-O-methyl glucose transport. Journal of Developmental Physiology 8, 247-253.

Rattray, P. V. \& Trigg, T. E. (1979). Minimal feeding of pregnant ewes. Proceedings of the New Zealand Society of Animal Production 39, 242-250.

Robinson, J. S., Kingston, E. J., Jones, C. T. \& Thorburn, G. D. (1979). Studies on experimental growth retardation in sheep. The effect of removal of endometrial caruncles on fetal size and metabolism. Journal of Developmental Physiology 1, 379-398.

Rodda, C. P., Kubota, M., Heath, J. A., Ebeling, P. R., Mosley, J. M., Care, A. D., Caple, I. W. \& Martin, T. J. (1988). Evidence for a novel parathyroid hormone-related protein in fetal lamb parathyroid glands implicated in humoral hypercalcaemia of malignancy. Journal of Endocrinology 117, 261-271.

Russel, A. J. F., Doney, J. M. \& Gunn, R. G. (1969). Subjective assessment of body fat in live sheep. Journal of Agricultural Science, Cambridge 72, 45I-454.

Russel, A. J. F., Foot, J. Z., White, I. R. \& Davies, G. J. (1981). The effect of weight at mating and of nutrition during mid pregnancy on the birth weight of lambs from primiparous ewes. Journal of Agricultural Science, Cambridge 97, 723-729.

Somogyi, M. (1945). Determinations of blood sugar. Journal of Biological Chemistry 160, 69-73.

Stacey, T. E., Weedon, A. P., Haworth, C. \& Ward, R. H. T. (1978). Feto-maternal transfer of glucose analogues by sheep placenta. Annales de Recherches Vétérinaires 8, 345-352.

Steel, J. W. \& Leng, R. A. (1968). Effect of plane of nutrition and pregnancy on glucose entry rates in sheep. Proceedings of the Ausiralian Society of Animal Production 7, 342-347.

Stegeman, J. H. J. (1974). Placental development in the sheep and its relationship to fetal development. Bijdragen tot de Dierkunde 44, 3-72.

Symonds, H. W., Manston, R., Payne, J. M. \& Sansom, B. F. (1966). Changes in the calcium and phosphorus requirements of the dairy cow at parturition with particular reference to the amounts supplied to the foetus in utero. British Veterinary Journal 122, 196-202.

Twardock, A. R., Symonds, H. W., Sansom, B. F. \& Rowlands, G. J. (1973). The effect of litter size upon foetal growth rate and placental transfer of calcium and phosphorus in superovulated Scottish half-bred ewes. British Journal of Nutrition 29, 437-446.

White, R. G.. Steel, J. W., Leng, R. A. \& Luick, R. J. (1969). Evaluation of three isotope-dilution techniques for studying the kinetics of glucose metabolism in sheep. Biochemical Journal 114, 203-214.

Widdas, W. F. (1952). Inability of diffusion to account for placental glucose transfer in the sheep and consideration of the kinetics of a possible carrier transfer. Journal of Physiology 118, 23-39.

Willis, J. B. (1960). The determination of metals in blood serum by atomic absorption spectrophotometry -1 . Calcium. Spectrochimica Acta 16, 259-272.

Willis, J. B. (1961). Determination of calcium and magnesium in urine by atomic absorption spectrophotometry. Analytical Chemistry 33, 556-559. 